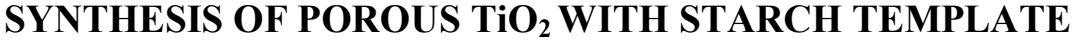 AND ITS PHOTOACTIVITY TOWARDS PHOTODEGRADATION OF METHYLENE BLUE
}

\author{
Gani Purwiandono ${ }^{a}$, IndrianaKartini ${ }^{\mathrm{b}}$ \\ ${ }^{\mathrm{a}}$ Departemen Kimia, FMIPA,Universitas Islam Indonesia \\ Jl. Kaliurang Km 14,5 Yogyakarta 55584 \\ E-mail: gani purwiandono@uii.ac.id \\ ${ }^{\mathrm{b}}$ Departemen Kimia, Universitas Gadjah Mada \\ Sekip Utara, Yogyakarta 55281
}

\begin{abstract}
ABSTRAK
Telah dilakukan penelitian mengenai sintesis $\mathrm{TiO}_{2}$ dengan cetakan pati menggunakan metode hidrotermal. Tujuan penelitian ini adalah mengkaji sifat kristalinitas dan porositas $\mathrm{TiO}_{2}$ berpori hasil sintesis serta aktivitas fotokatalitiknya dalam reaksi fotodegradasi zat warna metilen biru. $\mathrm{TiO}_{2}$ disintesis menggunakan pati dengan berat bervariasi $(0,5 \%, 2,5 \%, 5 \%, 10 \% \mathrm{~b} / \mathrm{v})$ dan tanpa pati. Pati dilarutkan dalam etanol dan dimasukkan ke dalam suspensi titanium (IV) tetraisopropoksida (TTIP). Proses hidrotermal dilakukan pada temperatur $100^{\circ} \mathrm{C}$ selama 4 jam. Cetakan pati dihilangkan melalui kalsinasi pada temperatur $450{ }^{\circ} \mathrm{C}$ selama 4 jam. $\mathrm{TiO}_{2}$ hasil sintesis dikarakterisasi menggunakan spektrofotometer FTIR. Pengaruh konsentrasi pati terhadap kristalinitas $\mathrm{TiO}_{2}$ dikaji menggunakan XRD. Porositas $\mathrm{TiO}_{2}$ yang diperoleh dikarakterisasi menggunakan $\mathrm{N}_{2}$ gas sorption analyzer. Aktivitas fotokatalitik $\mathrm{TiO}_{2}$ dikaji melalui fotodegradasi zat warna metilen biru.

Berdasarkan hasil $\mathrm{XRD}, \mathrm{TiO}_{2}$ hasil sintesis dengan pati sebagai cetakan pori menghasilkan serbuk $\mathrm{TiO}_{2}$ dengan fasa kristalin anatase. $\mathrm{TiO}_{2}$ dengan berat pati $5 \% \mathrm{~b} / \mathrm{v}$ memiliki fasa anatase dengan ukuran partikel 11,34 nm. Luas permukaan spesifik $\mathrm{S}_{\mathrm{BET}}$ $\mathrm{TiO}_{2}$ tersebut $110,19 \mathrm{~m}^{2} / \mathrm{g}$ dengan volum total pori $0,2 \mathrm{cc} / \mathrm{g}$ dan diameter pori $3,62 \mathrm{~nm}$. Hasil uji fotoaktivitas menunjukkan bahwa $\mathrm{TiO}_{2}$ dengan berat pati $5 \% \mathrm{~b} / \mathrm{v}$ mampu mendegradasi zat warna metilen biru hingga $56,9 \%$ dengan radiasi sinar UV selama 30 menit.
\end{abstract}

Kata Kunci: $\mathrm{TiO}_{2}$ mesopori, pati, templat, fotodegradasi, metilen biru

\begin{abstract}
Hydrothermal synthesis of $\mathrm{TiO}_{2}$ using starch as pores forming agent has been investigated. The research aimed to investigate the effect of crystallinity and porosity of $\mathrm{TiO}_{2}$ to its photocatalytic activity using photodegradation of methylene blue. $\mathrm{TiO}_{2}$ was synthesized without starch and with various strach concentration $(0.5 \%, 2.5 \%, 5 \%, 10 \%$ $\mathrm{w} / \mathrm{v})$. The starch was dissolved in ethanol, and then was added drop wisely into titanium (IV) tetraisopropoxide (TTIP) solution. The mixture was treated hydrothermally at $100{ }^{\circ} \mathrm{C}$ for $4 \mathrm{~h}$. Starch template was removed through calcination at $450{ }^{\circ} \mathrm{C}$ for $4 \mathrm{~h}$. The synthesized $\mathrm{TiO}_{2}$ was characterized by FT-IR spectrophotometry. The effect of starch concentration to $\mathrm{TiO}_{2}$ crystallinity was analyzed using XRD. The porosity of the synthesized $\mathrm{TiO}_{2}$ was determined using $\mathrm{N}_{2}$ gas sorption analyzer. The photocatalytic activity of $\mathrm{TiO}_{2}$ was monitored through the photodegradation of methylene blue.

The XRD patterns show that the $\mathrm{TiO}_{2}$ synthesized with various starch concentration consists mainly of anatase crystalline. The particle size of $\mathrm{TiO}_{2}$ synthesized with starch $5 \% \mathrm{w} / \mathrm{v}$ is $11.32 \mathrm{~nm}$ with the specific surface area $\left(\mathrm{S}_{\mathrm{BET}}\right)$ of $110.189 \mathrm{~m}^{2} / \mathrm{g}$, the total pore volume of $0.2 \mathrm{cc} / \mathrm{g}$ and the pore diameter of $3.62 \mathrm{~nm}$. The photoactivity test

Synthesis of Porous $\mathrm{TiO}_{2}$ with Starch Template and Its Photoactivity towards Photodegradation of Methylene Blue

(Gani Purwiandono, Indriana Kartini)


demonstrates that the synthesized $\mathrm{TiO}_{2}$ could degrade methylene blue up to $56.9 \%$ under UV irradiation for 30 minutes.

Key Words: mesoporous $\mathrm{TiO}_{2}$, starch, template, photodegradation, methylene blue

Pendahuluan

Material titanium dioksida $\left(\mathrm{TiO}_{2}\right)$
telah banyak diteliti dalam bidang
fotokatalis karena mempunyai
kemampuan menyerap cahaya yang
tinggi, ditandai dengan harga energi
celah pita (band gap, Eg) relatif besar,
bersifat inert baik secara biologi maupun
kimia, stabil terhadap fotokorosi dan
korosi oleh bahan kimia, serta murah ${ }^{[1]}$.

Mekanisme fotokatalis terjadi ketika suatu semikonduktor $\mathrm{TiO}_{2}$ dikenai sinar ultra violet, eksitasi elektron dari pita valensi semikonduktor menuju pita konduksi akan menghasilkan pasangan elektron $\left(\mathrm{e}_{\mathrm{cb}}^{-}\right)$dan hole $\left(\mathrm{h}_{\mathrm{vb}}^{+}\right)$yang dapat mengawali reaksi oksidasi-reduksi ${ }^{[2]}$.

Serbuk $\mathrm{TiO}_{2}$ dengan struktur anatase paling banyak digunakan karena mempunyai fotoaktivitas dan indeks bias tinggi, warna kuat, dan bersifat inert. Namun, secara termodinamika fasa anatase kurang stabil dibanding fasa rutile $^{[3]}$. Pembentukan fasa anatase lebih disukai pada temperatur rendah mulai $120{ }^{\circ} \mathrm{C}$ dan mencapai sempurna pada 500 ${ }^{\circ} \mathrm{C}$. Pada temperatur di atas $500{ }^{\circ} \mathrm{C}$ mulai terbentuk fasa rutile dan terjadi penurunan luas permukaan serta pelemahan aktvitas fotokatalis secara drastis ${ }^{[4]}$, sehingga pengaruh temperatur dalam sintesis padatan $\mathrm{TiO}_{2}$ perlu menjadi perhatian untuk menghasilkan padatan $\mathrm{TiO}_{2}$ dengan fasa kristal anatase.

Metode yang sering digunakan untuk menghasilkan $\mathrm{TiO}_{2}$ adalah sol-gel dan hidrotermal. Metode hidrotermal merupakan metode reaksi antara reaktan dengan air di dalam suatu wadah tertutup sedemikian rupa sehingga di dalam sistem tersebut terjadi kesetimbangan air pada temperatur dan tekanan yang tinggi. Metode ini memiliki beberapa keuntungan, antara lain tekniknya relatif sederhana, lebih baik dalam menghasilkan padatan kristal dan memiliki sifat fotokatalis dengan aktivitas tinggi serta temperatur yang digunakan untuk pembentukan fasa kristal anatase relatif rendah antara 120 ${ }^{\circ} \mathrm{C}$ mencapai sempurna pada $500{ }^{\circ} \mathrm{C}$, sedangkan metode sol-gel memerlukan temperatur diatas $500{ }^{\circ} \mathrm{C}$.

$$
\text { Pada awalnya, metode }
$$

hidrotermal dilakukan tanpa menggunakan cetakan pengarah pori sehingga ukuran kristal dan luas permukaan $\mathrm{TiO}_{2}$ yang terbentuk tidak dapat dikontrol ${ }^{[5]}$. Pada perkembangan selanjutnya, dikembangkan berbagai 
cetakan sebagai pengarah pembentukan pori dalam sintesis $\mathrm{TiO}_{2}$, sehingga dapat dihasilkan padatan $\mathrm{TiO}_{2}$ yang mempunyai luas permukaan dan volume pori tinggi dengan distribusi ukuran pori sempit serta diameter pori yang dapat diatur sesuai dengan cetakan. Adanya cetakan juga diharapkan mampu mengarahkan pembentukan kristal menuju fasa kristal anatase atau rutile sehinga dapat diperoleh kristal $\mathrm{TiO}_{2}$ dengan komposisi fasa yang dapat dikontrol dan mempunyai derajat kristalinitas yang tinggi. Davis dan Mann ${ }^{[6]}$ telah berhasil membuat monolit $\mathrm{TiO}_{2}$ mesopori dan makropori dengan menggunakan pati sebagai pencetak pori. Diperoleh monolit $\mathrm{TiO}_{2}$ berpori dengan ukuran pori sebesar $65 \AA$ dan luas permukaan spesifik mencapai $65 \mathrm{~m}^{2} / \mathrm{g}$. Mereka menyimpulkan bahwa konsentrasi berat pati dalam cetakan mempengaruhi porositas monolit $\mathrm{TiO}_{2}$ yang dihasilkan.

Serbuk $\mathrm{TiO}_{2}$ yang baik digunakan sebagai fotokatalis minimal memiliki penyusun kristalinitas dengan komposisi $80 \%$ anatase dan $20 \%$ rutile pada ukuran kristal 20-30 nm ${ }^{[7]}$. Cheng et al. ${ }^{[8]}$ telah mengkaji aktivitas fotokatalis $\mathrm{Zn}$ dopped $\mathrm{TiO}_{2}$ dibandingkan dengan $\mathrm{TiO}_{2}$ komersil P25 Degussa yang bergantung pada luas permukaan dan komponen fotoaktif dalam reaksi fotodegradasi.

Synthesis of Porous $\mathrm{TiO}_{2}$ with Starch Template and Its Photoactivity towards Photodegradation of Methylene Blue

(Gani Purwiandono, Indriana Kartini)

\section{Tujuan Penelitian}

Pada penelitian ini akan dilakukan sintesis $\mathrm{TiO}_{2}$ dengan pati sebagai pencetak pori melalui metode hidrotermal. Fotoaktivitas $\mathrm{TiO}_{2}$ hasil sintesis sebagai fotokatalis dikaji melalui fotodegradasi zat warna metilen biru dan dibandingkan dengan aktivitas fotokatalis komersial $\mathrm{TiO}_{2}$ P25 produksi Degussa (Jerman).

\section{Metode Penelitian}

Penelitian dilakukan di Laboratorium Kimia Universitas Gadjah Mada, Yogyakarta. Bahan yang digunakan di dalam penelitian ini adalah: soluble starch/pati, etanol p.a., metilen biru (Merck) dan titanium (IV) tetraisopropoksida (TTIP 97\%, Aldrich). Peralatan penelitian yang digunakan meliputi seperangkat alat gelas, hot plate, pengaduk magnet, furnace, centrifuge, dan termometer. Peralatan karakterisasi antara lain Spektrofotometer UV-Vis (Genesys 20), satu set reaktor yang dilengkapi dengan lampu UV 20 watt seri MLW (Philips) yang memiliki $\lambda 254 \mathrm{~nm}$, Spektrofotometer inframerah Shimadzu8021 PC, Diffuse Reflectance UV (ISR240A), Difraktogram sinar-X (Shimadzu model XRD-6000 Elmer), dan Gas Sorption Analyser (NOVA-1000). 


\section{Pembahasan}

\section{Sintesis $\mathrm{TiO}_{2}$}

Sintesis $\mathrm{TiO}_{2}$ berpori dilakukan dengan metode hidrotermal menggunakan soluble starch (pati) sebagai pencetak pori. Digunakan Titanium (IV) tetraisopropoksida (TTIP) sebagai prekursor Ti karena struktur ini dapat membatasi akses molekul air untuk memutuskan ikatan Ti-O pada TTIP sehingga laju hidrolisis dapat diperlambat dan pembentukan kristal dapat diatur.

Selama proses hidrotermal berlangsung, reaksi hidrolisis dan polikondensasi terjadi secara simultan ketika sejumlah larutan prekursor titanium (IV) tetraisopopoksida (TTIP)

bercampur air dalam pelarut etanol pada temperatur dan tekanan yang tinggi. Nanopartikel titania dalam sistem dispersi suspensi dapat tersisipkan pada permukaan internal maupun eksternal cetakan dan mengalami polikondensasi membentuk jaringan oksida titania.

Reaksi ini akan mendorong pembentukan polimer dengan berat molekul yang lebih besar, dengan demikian deposisi jaringan oksida titania akan menghasilkan suatu struktur titania berpori ketika dilakukan proses penghilangan cetakan (kalsinasi). Model pembentukan struktur titania berpori yang diusulkan ditampilkan pada Gambar 1.
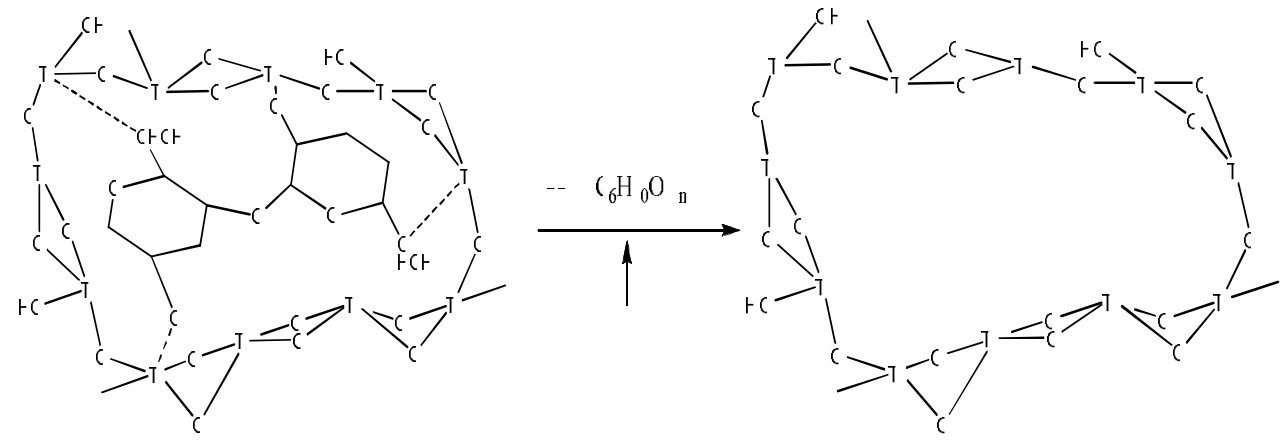

Gambar 1. Model interaksi pembentukan $\mathrm{TiO}_{2}$ dengan cetakan pati

Analisis hilangnya pati dari $\mathrm{TiO}_{2}$ hasil sintesis dilakukan menggunakan FTIR. Analisis spektra FTIR dilakukan terhadap $\mathrm{TiO}_{2}$ hasil sintesis sebelum dan setelah proses kalsinasi sebagaimana disajikan pada Gambar 2.

Puncak lebar pada daerah 600$400 \mathrm{~cm}^{-1}$ yang muncul pada spektra FTIR serbuk $\mathrm{TiO}_{2}$ hasil sintesis dengan cetakan pati teridentifikasi sebagai kerangka dasar $\mathrm{TiO}_{2}$. Serapan yang muncul di daerah $1080,14 \mathrm{~cm}^{-1}$ pada spektra $\mathrm{TiO}_{2}$ dengan berat pati $5 \% \mathrm{~b} / \mathrm{v}$ sebelum kalsinasi dimungkinkan merupakan serapan C-O-Ti dan tidak muncul kembali pada spektra $\mathrm{TiO}_{2}$ dengan berat

Synthesis of Porous $\mathrm{TiO}_{2}$ with Starch Template and Its Photoactivity towards Photodegradation of Methylene Blue 
pati $5 \% \mathrm{~b} / \mathrm{v}$ setelah kalsinasi. Hal ini mengindikasikan bahwa pati yang berfungsi sebagai cetakan pori dalam sintesis $\mathrm{TiO}_{2}$ dapat dihilangkan setelah proses kalsinasi pada temperatur $450{ }^{\circ} \mathrm{C}$ selama 4 jam.

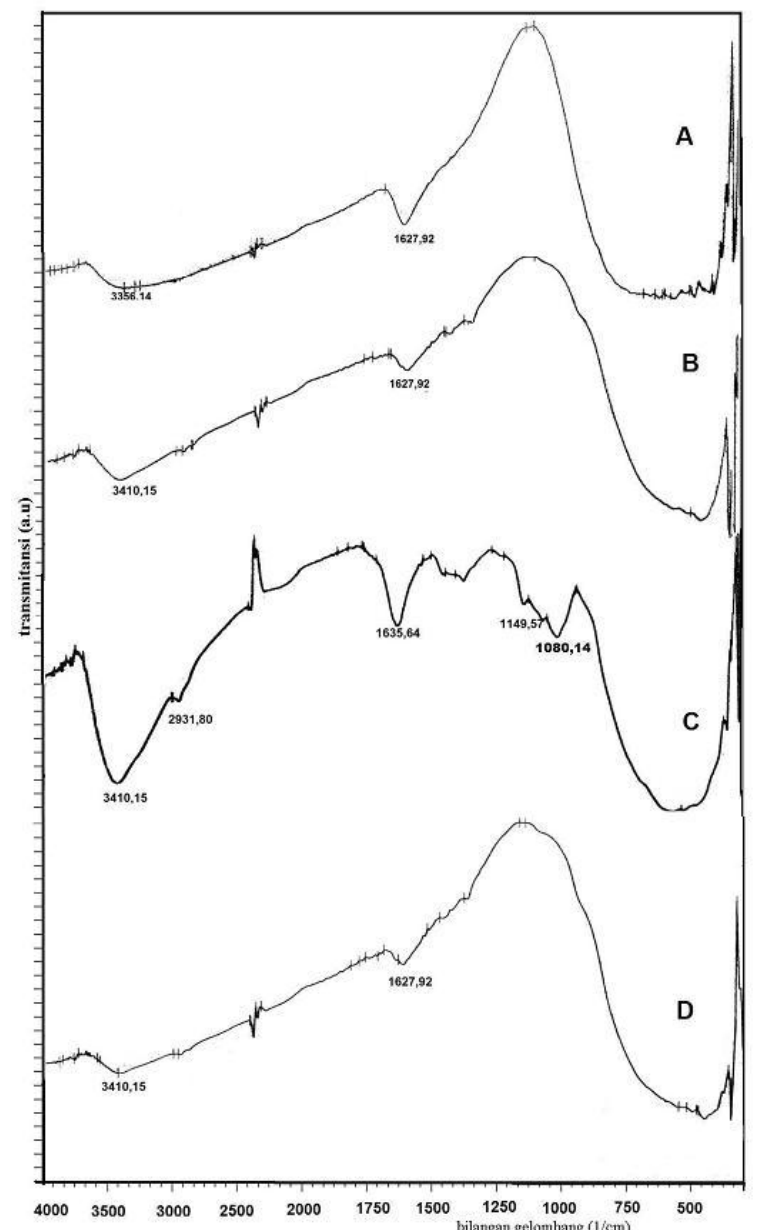

Gambar 2. Spektra FTIR serbuk $\mathrm{TiO}_{2}$ hasil sintesis tanpa cetakan (a) sebelum kalsinasi

(b) setelah kalsinasi (c) $\mathrm{TiO}_{2}$ hasil sintesis dengan berat pati $5 \% \mathrm{~b} / \mathrm{v}$ sebelum kalsinasi (d) setelah kalsinasi.

Puncak yang muncul di daerah 1635,64 $\mathrm{cm}^{-1}$ pada spektra $\mathrm{TiO}_{2}$ dengan cetakan pati sebelum kalsinasi menunjukkan vibrasi tekuk $\mathrm{OH}$ dari $\mathrm{H}_{2} \mathrm{O}$, sedangkan pada spektra FTIR setelah kalsinasi puncak tersebut bergeser pada $1627,92 \mathrm{~cm}^{-1}$ yang juga menunjukkan vibrasi tekuk $\mathrm{OH}$ dari $\mathrm{H}_{2} \mathrm{O}$. Puncak di daerah $1627,92 \mathrm{~cm}^{-1}$ dan $3410,15 \mathrm{~cm}^{-1}$ setelah kalsinasi mengalami penurunan intensitas yang menandakan bahwa jumlah $\mathrm{OH}$ dalam serbuk $\mathrm{TiO}_{2}$ berkurang. Serbuk $\mathrm{TiO}_{2}$ diketahui bersifat higroskopis sehingga sangat mudah menyerap molekul $\mathrm{H}_{2} \mathrm{O}$. Meskipun serbuk $\mathrm{TiO}_{2}$ telah dikalsinasi pada $450{ }^{\circ} \mathrm{C}$, ternyata masih terdapat indikasi molekul $\mathrm{H}_{2} \mathrm{O}$ pada $\mathrm{TiO}_{2}$ hasil Synthesis of Porous $\mathrm{TiO}_{2}$ with Starch Template and Its Photoactivity towards Photodegradation of Methylene Blue 
sintesis. Hal ini terjadi karena terserapnya $\mathrm{H}_{2} \mathrm{O}$ kembali dari udara luar setelah proses sintering maupun selama penyimpanan sebelum analisis dilakukan.

Tabel 1. Serapan spektra FTIR $\mathrm{TiO}_{2}$ hasil sintesis dengan berat pati 5\% b/v

\begin{tabular}{|c|c|c|c|}
\hline \multicolumn{4}{|c|}{ Bilangan Gelombang $\left(\mathrm{cm}^{-1}\right)$} \\
\hline Referensi & $\begin{array}{c}\mathrm{TiO}_{2} \text { hasil } \\
\text { sintesis sebelum } \\
\text { kalsinasi }\end{array}$ & $\begin{array}{c}\mathrm{TiO}_{2} \text { hasil sintesis } \\
\text { setelah kalsinasi }\end{array}$ & Serapan karakteristik \\
\hline $3448,5^{[9]}$ & 3410,15 & 3410,15 & OH renggang dari $\mathrm{H}_{2} \mathrm{O}$ \\
$1639,4^{[10]}$ & 1635,64 & 1627,92 & OH tekuk dari $\mathrm{H}_{2} \mathrm{O}$ \\
$3000-2800^{[10]}$ & 2931,80 & 2924,09 & Serapan C-H dari pati \\
$1080^{[11]}$ & 1080,14 & - & Serapan C-O-Ti \\
$900-400^{[11]}$ & $\begin{array}{c}\text { Serapan lebar } \\
\text { dan tajam pada } \\
\end{array}$ & $\begin{array}{c}\text { Serapan lebar dan } \\
\text { tajam pada 600-400 }\end{array}$ & Karakteristik $\mathrm{TiO}_{2}\left(\mathrm{v}_{\text {Ti-O-Ti }}\right)$ \\
& $600-400$ & & \\
\hline
\end{tabular}

\section{Kristalinitas $\mathrm{TiO}_{2}$ Hasil Sintesis}

Difraktogram sinar-X $\mathrm{TiO}_{2}$ hasil sintesis dengan variasi berat pati secara berurutan disajikan pada Gambar 3. $\mathrm{TiO}_{2}$ hasil sintesis mempunyai kristalinitas yang tinggi dan dominan tersusun atas fasa anatase. Hal ini ditunjukkan dengan kehadiran puncak tajam pada daerah $2 \theta$ sekitar $25^{\circ}$ masing-masing serbuk $\mathrm{TiO}_{2}$ hasil sintesis. Puncak anatase tertinggi dihasilkan oleh $\mathrm{TiO}_{2}$ dengan berat pati $5 \% \mathrm{~b} / \mathrm{v}$ dengan puncak anatase pada $\mathrm{d}_{101}=3,53485$. Penggunaan cetakan dalam konsentrasi yang tinggi akan menekan pertumbuhan kristal rutile dan mengarahkan pada pembentukan kristal anatase, sedangkan pada konsentrasi yang berlebih, partikel titania akan terbungkus oleh block copolymer molekul cetakan, sehingga pembentukan kristal menjadi terhambat ${ }^{[12,13]}$. Hal ini yang menjelaskan fenomena berkurangnya derajat kristalinitas $\mathrm{TiO}_{2}$ dengan berat pati $10 \% \mathrm{~b} / \mathrm{v}$ karena pengaruh penggunaan pati dalam jumlah banyak akan menyebabkan pertumbuhan kristal menjadi tidak sempurna akibat dari panjang rantai karbon makromolekul pati yang menghambat pertumbuhan kristal anatase.

Berdasarkan persamaan Scherrer, dapat ditentukan ukuran kristal (D). Komposisi fasa kristal anatase dan rutile serbuk $\mathrm{TiO}_{2}$ disajikan pada Tabel 2 . 


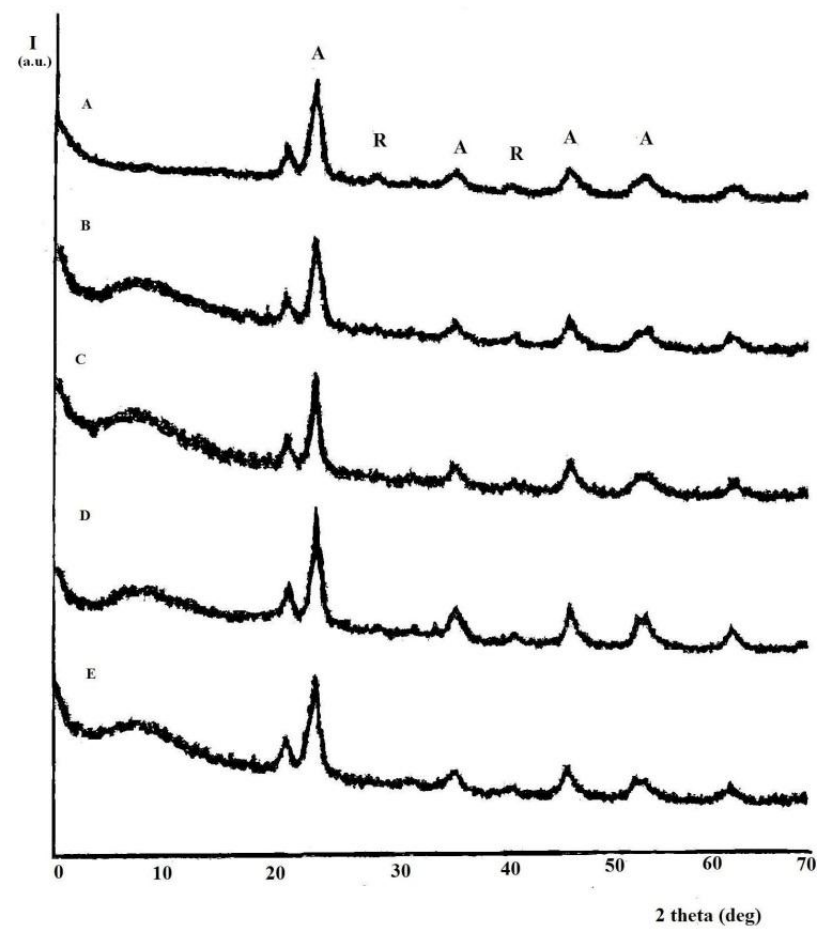

Gambar 3. Difraktogram serbuk $\mathrm{TiO}_{2}$ hasil sintesis dengan variasi berat pati, anatase (A) dan rutile (R) (a) tanpa cetakan (b) $0,5 \%$ b/v (c) $2,5 \%$ b/v (d) $5 \%$ b/v (e) $10 \%$ b/v.

Tabel 2. Ukuran fasa kristal serbuk $\mathrm{TiO}_{2}$ dengan variasi berat pati

\begin{tabular}{|l|c|c|c|c|c|c|}
\hline \multirow{2}{*}{\multicolumn{1}{|c|}{ Sampel $\mathrm{TiO}_{2}$}} & \multicolumn{3}{|c|}{ Anatase } & \multicolumn{3}{c|}{ Rutile } \\
\cline { 2 - 7 } & $2 \theta\left(^{\circ}\right)$ & $\mathrm{d}(\AA)$ & $\mathrm{D}(\mathrm{nm})$ & $2 \theta\left(^{\circ}\right)$ & $\mathrm{d}(\AA)$ & $\mathrm{D}(\mathrm{nm})$ \\
\hline Data JCPDS & & 3,5200 & & & 3,2470 & \\
Tanpa cetakan & 25,443 & 3,4979 & 9,676 & 27,160 & 3,2806 & 14,59 \\
Berat pati $0,5 \% \mathrm{~b} / \mathrm{v}$ & 25,522 & 3,4873 & 7,631 & 27,380 & 3,2548 & 12,74 \\
Berat pati $2,5 \% \mathrm{~b} / \mathrm{v}$ & 25,607 & 3,4767 & 7,218 & 27,700 & 3,2179 & 8,500 \\
Berat pati $5 \% \mathrm{~b} / \mathrm{v}$ & 25,173 & 3,5349 & 11,34 & - & - & - \\
Berat pati $10 \% \mathrm{~b} / \mathrm{v}$ & 25,454 & 3,4965 & 7,404 & - & - & - \\
\hline
\end{tabular}

Faktor yang menentukan pengarah pori. Fenomena ini disebabkan pembentukan fasa anatase pada serbuk karena cetakan pati menyediakan ruang $\mathrm{TiO}_{2}$ hasil sintesis yakni pengaruh yang relatif sempit, sehingga dapat temperatur, sedangkan pengaruh cetakan berperan sebagai material inang dalam pati yang berlebih dapat menghambat pertumbuhan fasa kristal anatase. membatasi pertumbuhan kristal anatase.

Pertumbuhan kedua fasa kristal anatase Berdasar data hasil difraktogram dan rutile dipengaruhi oleh faktor pada Gambar 3, secara kualitatif dapat ketersediaan ruang yang dibatasi oleh diketahui bahwa $\mathrm{TiO}_{2}$ hasil sintesis dengan variasi berat pati secara dominan banyaknya jumlah cetakan sebagai tersusun atas fasa anatase. Padatan titania

Synthesis of Porous $\mathrm{TiO}_{2}$ with Starch Template and Its Photoactivity towards Photodegradation of Methylene Blue 
hasil sintesis dikarakterisasi lebih lanjut untuk mengetahui karakter porositas dan distribusi pori.

\section{Porositas $\mathrm{TiO}_{2}$ Hasil Sintesis}

Luas permukaan dan distribusi ukuran pori ditentukan dengan metode Brunauer - Emmet - Teller (BET), sedangkan distribusi ukuran pori ditentukan dengan metode Barret-JoynerHalenda (BJH) jalur desorpsi. Kurva isoterm adsorpsi disajikan pada Gambar 4. Berdasar Gambar 4, kurva isoterm adsorpsi desorpsi menujukkan terjadinya histeresis.

Adanya histeresis menandakan bahwa gas yang telah teradsorp mengalami desorpsi relatif berdasar ukuran permukaan pori karena adanya kondensasi kapiler pada mesopori. Pola isoterm pada kurva titania hasil sintesis tanpa cetakan memiliki pola mesopori dengan adanya histeresis dan pola desorpsi menunjukkan keragaman jenis pori hanya pada pori berukuran meso.

Data kuantitatif porositas berbagai padatan titania disajikan pada Tabel 3 . Padatan titania dengan cetakan $5 \% \mathrm{~b} / \mathrm{v}$ memiliki karakter pori dengan luas permukaan spesifik mencapai 110,189 $\mathrm{m}^{2} / \mathrm{g}$ dengan jejari pori sebesar $1,81 \mathrm{~nm}$ dan volume total pori $0,991 \mathrm{~cm}^{3} / \mathrm{g}$, sedangkan titania tanpa cetakan memiliki volume total pori $0,190 \mathrm{~cm}^{3} / \mathrm{g}$, yang mengindikasikan bahwa pori titania dengan pati sebagai cetakan memiliki rongga dan ruang yang relatif besar dibanding padatan titania tanpa cetakan.
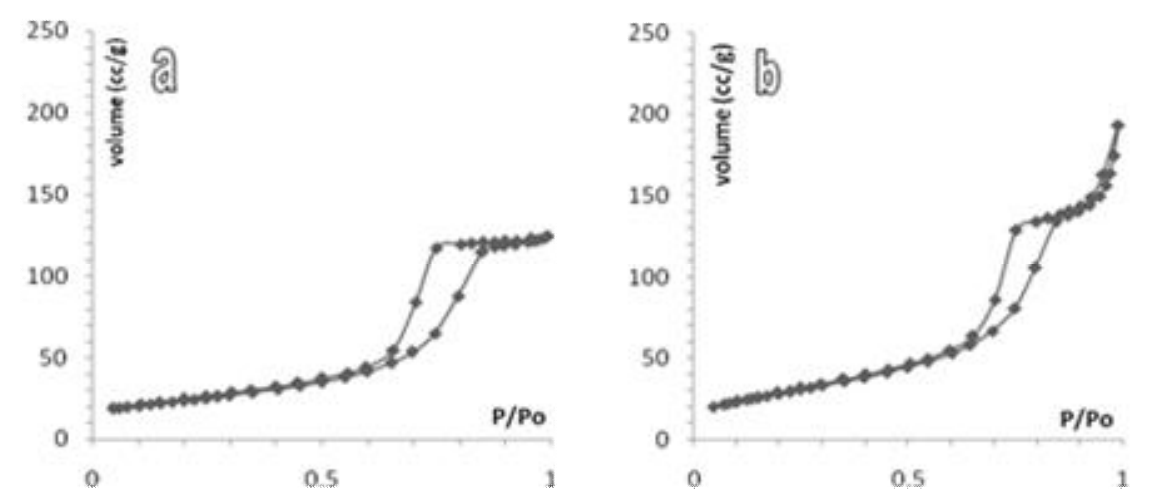

Synthesis of Porous $\mathrm{TiO}_{2}$ with Starch Template and Its Photoactivity towards Photodegradation of Methylene Blue 

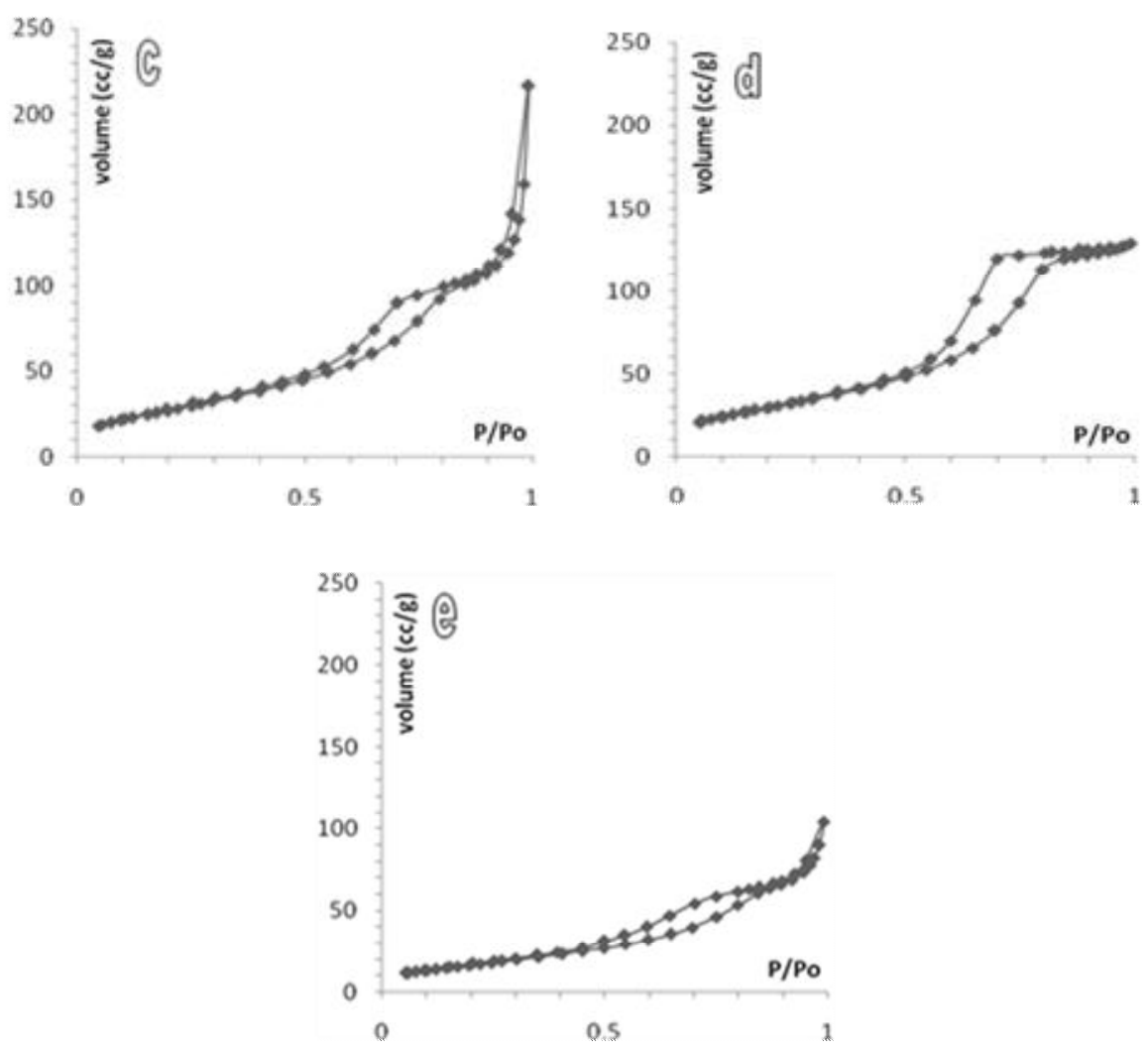

Gambar 4. Kurva isoterm adsorpsi desorpsi $\mathrm{TiO}_{2}$ (a) tanpa cetakan (b) cetakan pati 0,5\% $\mathrm{b} / \mathrm{v}$ (c) cetakan pati $2,5 \% \mathrm{~b} / \mathrm{v}$ (d) cetakan pati $5 \% \mathrm{~b} / \mathrm{v}$ (e) cetakan pati $10 \% \mathrm{~b} / \mathrm{v}$

Tabel 3. Hasil uji kuantitatif analisis isoterm adsorpsi-desorpsi gas $\mathrm{N}_{2}$

\begin{tabular}{|l|c|c|c|}
\hline \multicolumn{1}{|c|}{$\mathrm{TiO}_{2}$ hasil sintesis } & $\begin{array}{c}\text { Luas permukaan } \\
\text { spesifik }\left(\mathrm{m}^{2} / \mathrm{g}\right)^{*}\end{array}$ & $\begin{array}{c}\text { Volume pori total } \\
\left(\mathrm{cm}^{3} / \mathrm{g}\right)^{*}\end{array}$ & $\begin{array}{c}\text { Diameter pori } \\
\text { rerata }(\AA) * *\end{array}$ \\
\hline Tanpa cetakan & 83,366 & 0,190 & 46,15 \\
Cetakan pati $0,5 \% \mathrm{~b} / \mathrm{v}$ & 105,512 & 0,990 & 56,71 \\
Cetakan pati $2,5 \% \mathrm{~b} / \mathrm{v}$ & 104,97 & 0,990 & 43,78 \\
Cetakan pati $5 \% \mathrm{~b} / \mathrm{v}$ & 110,189 & 0,991 & 38,07 \\
Cetakan pati $10 \% \mathrm{~b} / \mathrm{v}$ & 63,54 & 0,991 & 50,69 \\
\hline
\end{tabular}

Berdasarkan intepretasi kurva isoterm pada Gambar 4 dan data kuantitatif dalam Tabel 3, dapat diketahui bahwa penggunaan cetakan pati dalam sintesis padatan titania menyebabkan pembentukan pori yang ditandai dengan nilai volume total pori naik secara signifikan antara padatan titania yang menggunakan cetakan dengan tanpa cetakan. Padatan titania dengan cetakan pati $5 \% \mathrm{~b} / \mathrm{v}$ memiliki luas permukaan spesifik yang paling besar akan tetapi nilai diameter pori rerata paling kecil, hal ini dimungkinkan karena kerusakan lokal (local collapse) dalam struktur pori internal titania selama proses kalsinasi. 
Laju pemanasan kalsinasi yang tidak teratur tidak mampu menfasilitasi penghilangan cetakan secara bertahap dan sempurna dan dapat memicu kerusakan lokal terhadap pori yang telah terbentuk. Kurva isoterm adsorpsidesorpsi monolit titania hasil sintesis memiliki fenomena histeresis yang besar. dalam padatan titania dapat dikonfirmasi melalui plot kurva $d V(r)$ versus $r$ pada jalur desorpsi berdasarkan metode BJH. Hasil intepretasi kurva distribusi pori dapat memberikan informasi yang bermanfaat dalam menggambarkan keseragaman ukuran pori dalam suatu padatan.

Distribusi ukuran pori yang tersebar

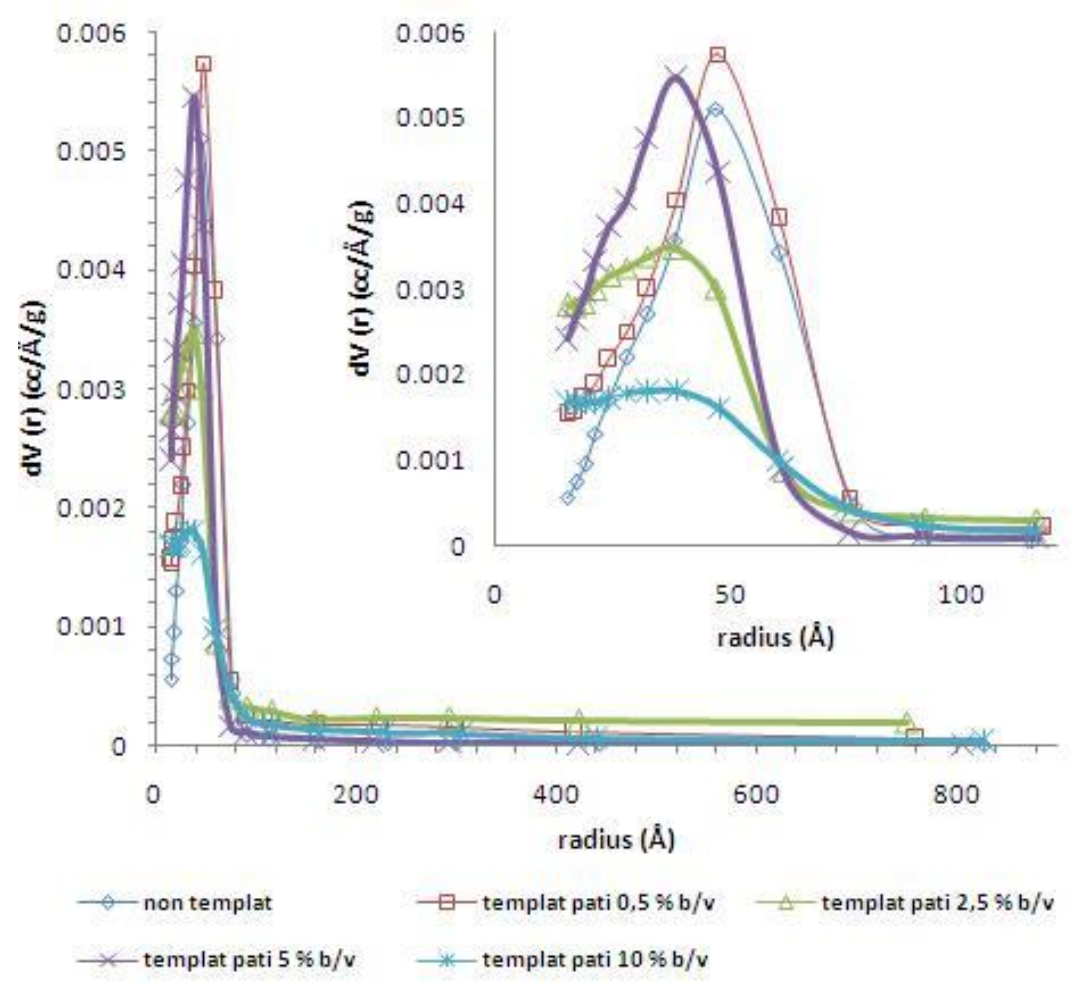

Gambar 5. Kurva distribusi ukuran pori BJH dalam padatan titania dengan variasi berat cetakan. Perbesaran radius $0-100 \AA$

Padatan titania dengan pori yang seragam mampu menyediakan situs permukaan dengan orientasi yang relatif sama untuk berinteraksi dengan adsorbat (metilen biru). Sementara padatan titania dengan distribusi pori yang acak akan memberikan kapasitas dan lama adsorbsi yang berbeda. Hal ini berpengaruh terhadap keseragaman lapisan molekul zat warna pada permukaan titania, sehingga dapat mempengaruhi kinerja fotokatalitik. Ukuran radius pori ini menunjukkan bahwa titania hasil sintesis

Synthesis of Porous $\mathrm{TiO}_{2}$ with Starch Template and Its Photoactivity towards Photodegradation of 
memiliki keseragaman pori yang besar dengan karakter mesopori.

\section{Sifat Fotokatalitik $\mathrm{TiO}_{2}$ Hasil Sintesis}

Reaksi fotodegradasi metilen biru pada dasarnya merupakan reaksi reduksioksidasi yang diinduksi oleh sinar ultra violet. Metilen biru (substrat) berperan sebagai reduktor, oksigen sebagai oksidator, sedangkan $\mathrm{TiO}_{2}$ bertindak sebagai fotokatalis. Sistem reaksi fotooksidasi dengan fotokatalis titania dilakukan melalui penyinaran cahaya UV dengan energi yang sesuai dengan energi celah pita semikonduktor $\mathrm{TiO}_{2}(\lambda \leq 385)$.

Efektivitas fotodegradasi metilen biru menggunakan fotokatalis dihitung dengan mengevaluasi konsentrasi metilen biru dalam keadaan terang $\left(\mu_{2}\right)$ dengan konsentrasi metilen biru dalam keadaan gelap $\left(\mu_{1}\right)$ pada adsorbansi padatan titania hasil sintesis. Adanya proses degradasi metilen biru membuktikan bahwa $\mathrm{TiO}_{2}$ mempunyai aktivitas fotokatalik.

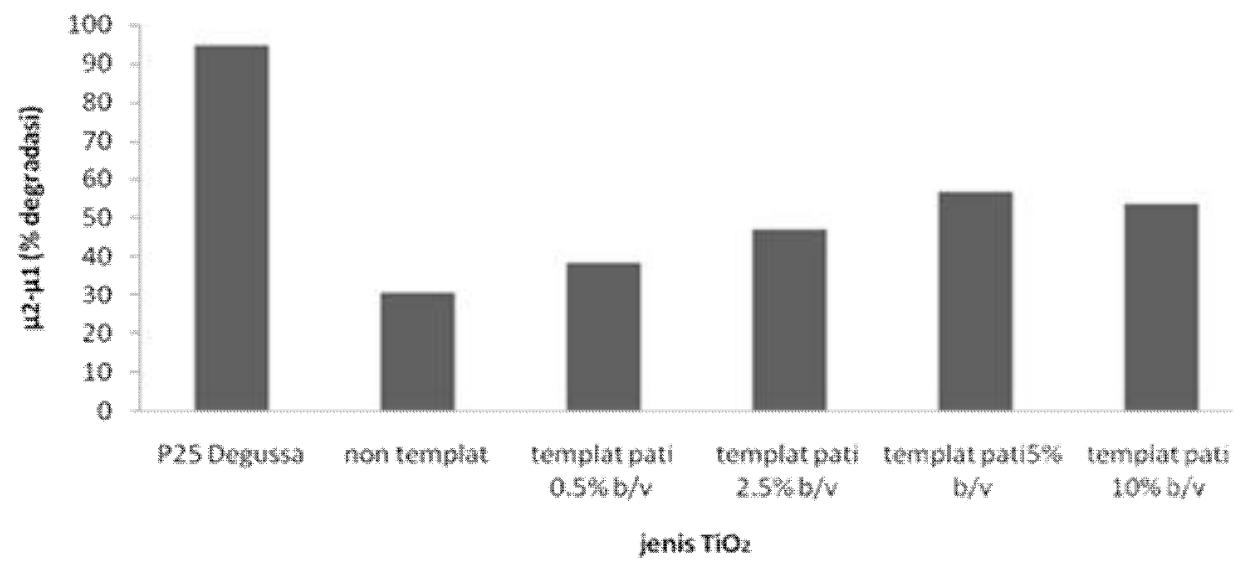

(a)

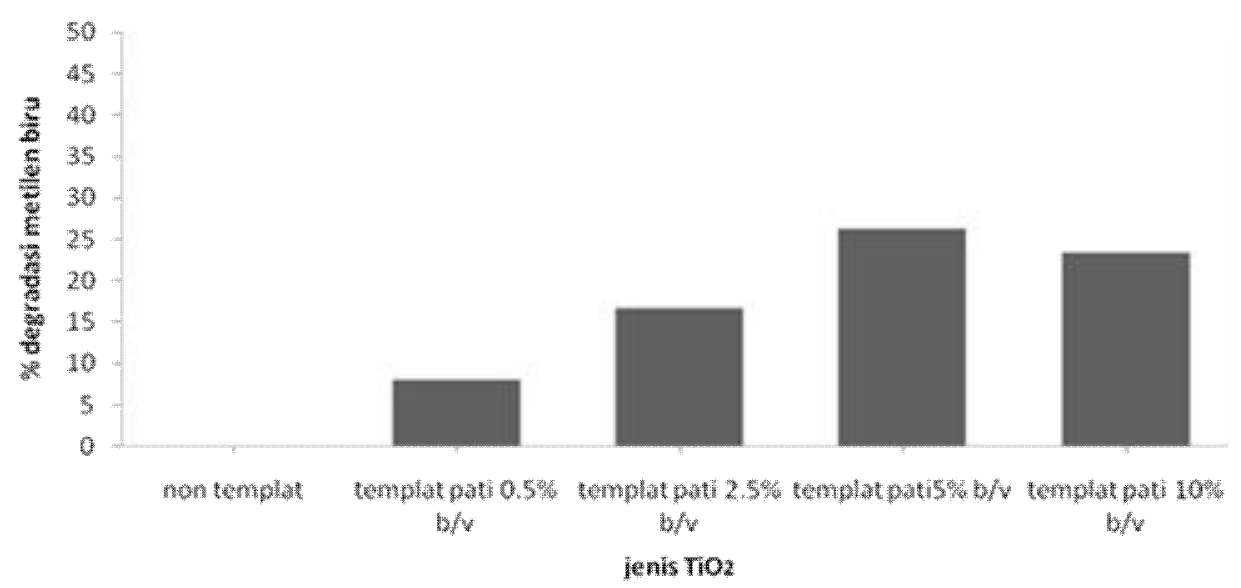

(b)

Gambar 6. (a) Aktivitas fotodegradasi metilen biru menggunakan $\mathrm{TiO}_{2}$ hasil sintesis (b) efektivitas relatif $\mathrm{TiO}_{2}$ dibanding $\mathrm{TiO}_{2}$ tanpa cetakan. 
Aktivitas fotokatalitik $\mathrm{TiO}_{2}$ hasil sintesis terhadap metilen biru mencapai optimum pada $\mathrm{TiO}_{2}$ dengan cetakan pati $5 \% \mathrm{~b} / \mathrm{v}$ sebesar $26,3 \%$ relatif dibanding $\mathrm{TiO}_{2}$ tanpa cetakan. Hal ini sesuai dengan karakter luas permukaan spesifik dan volume pori total yang besar. Penurunan aktivitas fotokatalik $\mathrm{TiO}_{2}$ dengan cetakan pati $10 \% \mathrm{~b} / \mathrm{v}$ terjadi karena penurunan kristal anatase yang terbentuk akibat konsentrasi cetakan berlebih dan menyebabkan menurunnya aktivitas fotokatalitik. Digunakan pembanding $\mathrm{TiO}_{2} \quad \mathrm{P} 25$ Degussa yang dapat mendegradasi metilen biru hingga $94,87 \% \quad$ (Tabel 4) dikarenakan kristalinitas penyusun $\mathrm{TiO}_{2}$ P25 Degussa sangat baik dengan ukuran kristal anatase $35,1551 \mathrm{~nm}$.

Tabel 4. Perbandingan fotoaktivitas $\mathrm{TiO}_{2}$

\begin{tabular}{|c|c|}
\hline Jenis $\mathrm{TiO}_{2}$ & $\begin{array}{c}\text { Degradasi } \\
\text { metilen biru (\%) }\end{array}$ \\
\hline $\begin{array}{c}\mathrm{TiO}_{2} \text { cetakan pati } \\
5 \% \mathrm{~b} / \mathrm{v}\end{array}$ & 56,90 \\
\hline P25 Degussa & 94,87 \\
\hline
\end{tabular}

Faktor kristalinitas fasa kristal anatase mengalami peningkatan seiring dengan penambahan cetakan pati dan terbukti memberikan peningkatan efektivitas fotodegradasi metilen biru. Efektivitas titania P25 mencapai 94,87\% dengan kristal penyusun anatase mencapai 79\% dan ukuran kristal 35,15 nm, walaupun P25 tidak memiliki keseragaman pori yang baik, akan tetapi Synthesis of Porous $\mathrm{TiO}_{2}$ with Starch Template and Its Photoactivity towards Photodegradation of Methylene Blue (Gani Purwiandono) memiliki struktur dan ukuran fasa anatase yang dominan. Faktor konsentrasi cetakan pati memberikan faktor kristalinitas yang baik dan fotoaktivitas degradasi metilen biru, akan tetapi tidak berpengaruh terhadap porositas $\mathrm{TiO}_{2}$ hasil sintesis.

\section{Kesimpulan}

Berdasarkan penelitian dan pembahasan dapat disimpulkan bahwa sintesis $\mathrm{TiO}_{2}$ melalui metode hidrotermal menghasilkan $\mathrm{TiO}_{2}$ berpori dengan fasa kristal anatase. Aktivitas $\mathrm{TiO}_{2}$ dengan berat pati $5 \% \mathrm{~b} / \mathrm{v}$ dengan radiasi UV selama 30 menit mampu mendegradasi metilen biru sebesar $56,90 \%$ dan penurunan konsentrasi metilen biru pada reaksi fotokatalitik dipengaruhi oleh faktor kristalinitas $\mathrm{TiO}_{2}$ hasil sintesis.

\section{Pustaka}

[1] Hoffman, M.R., Martin, S.M., Choi, W., and Bahnemann, D.W., 1995, Enviromental Application of Semiconductor Photocatalyst, Chem. Rev. B., 95, 69-96

${ }^{[2]}$ Lee, G.D., and Falconer, J.L., 2000, Transient Measurments of lattice Oxigen in Photocatalytic Decomposition of Formic Acid on $\mathrm{TiO}_{2}$, Catal. Lett., 70, 145-148

[3] Yanagisawa, K., and Ovenstone, J., 1999, Crystalization of Anatase from Amorphous Titania Using the Hydrotermal Technique: Effect of Starting Material and Temperature, $J$. Phys. Chem. B., 103, 7781-7787 
[4] Ollis, D.F., and Elkabi, 1993, Photocatalytic Purification and Treatment of Water and Air,Elseiver, Amsterdam

${ }^{[5]}$ Awati, P.S., Awate, S.V., Shah, P.P., and Ramaswamy, V., 2003, Photocatalytic Decomposition of Metylene Blue Using Nanocrystalline Anatase Titania Prepared by Ultrasonic Technique, Catal. Commun., 4, 393-400

[6] Davis, S.A., and Mann, S., 2004, Spongelike Macroporous $\mathrm{TiO}_{2}$ Monoliths Prepared from Starch Gel Template, Sol-Gel Sci. Technol., 32, 95105

${ }^{[7]}$ Meilert, K.T., Laub, D, and Kiwi, J., 2005, Photocatalytic selfcleaning of Modified Cotton Textiles by $\mathrm{TiO}_{2}$ Clusters Attached by Chemical spacers, J. Photochem. Photobiol., 174, 156-164

${ }^{[8]}$ Cheng, H., Ma, J., Zhao, Z., and Qi, L., 1995, Hydrotermal Preparation of Uniform Nanosized Rutile and Anatase Particles, Chem. Mater., 7 (4), 663

${ }^{[9]}$ Meilert, K.T., Laub, D, and Kiwi, J., 2005, Photocatalytic selfcleaning of Modified Cotton Textiles by $\mathrm{TiO}_{2}$ Clusters Attached by Chemical spacers, J. Photochem. Photobiol., 174, 156-164

${ }^{[10]}$ Yang, P., Zhao, D., Margolese, D.I., Chmelka, F.B., and Stucky, G.D., 1999, Block Copolymer Templating Synthesis of Mesoporous Metal Oxides with Large Ordering Lenghts and Semicrystalline Framework, Chem. Mater., 11 (10), 2813-2826

[11] Kumar, P., Badrinarayanan, S., and Sastry, M., 1999, Nanocrystalline $\mathrm{TiO}_{2}$ Studied by Optical, FT-IR and X-Ray Photoelectron Spectroscopy: Correlation to Presence of Surface States, Thin Solid Films 358, 122-130

[12] Kartini, I., 2004, Synthesis and Characterization of Mesostructured Titania for Photoelectrochemical Solar Cells, PhD Thesis, Chemical Engineering, The University of Queensland, Australia

${ }^{[13]}$ Kartini, I., 2009, Sel Surya Berbasis Sistem Sandwich Nanokristal Semikonduktor Celah Lebar dan Zat Warna Alam (Natural Dye-Sensitized Solar Cell, nDSSC), Inorganic Chemistry Laboratory, Department of Chemistry, UGM, Yogyakarta 